Western University

Scholarship@Western

Aboriginal Policy Research Consortium International (APRCi)

6-27-2011

\title{
A critical review of Aboriginal education in Canada: Eurocentric dominance impact and everyday denial
}

Erica Neeganagwedgin

Erica.neegan@utoronto.ca

Follow this and additional works at: https://ir.lib.uwo.ca/aprci

Citation of this paper:

Neeganagwedgin, Erica, "A critical review of Aboriginal education in Canada: Eurocentric dominance impact and everyday denial" (2011). Aboriginal Policy Research Consortium International (APRCi). 440.

https://ir.lib.uwo.ca/aprci/440 
This article was downloaded by: [University of Western Ontario]

On: 07 December 2012, At: 07:13

Publisher: Routledge

Informa Ltd Registered in England and Wales Registered Number: 1072954 Registered

office: Mortimer House, 37-41 Mortimer Street, London W1T 3J H, UK

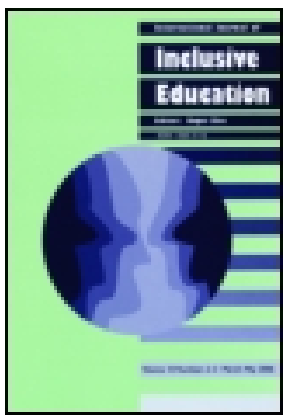

\section{International J ournal of Inclusive Education}

Publication details, including instructions for authors and subscription information:

http:// www.tandfonline.com/loi/tied20

\section{A critical review of Aboriginal education in Canada: Eurocentric dominance impact and everyday denial}

Erica Neeganagwedgin ${ }^{a}$

a 218 Queens Quay West, Suite 501-Toronto, Ontario, M5J 2Y6, Canada

Version of record first published: 27 J un 2011.

To cite this article: Erica Neeganagwedgin (2011): A critical review of Aboriginal education in Canada: Eurocentric dominance impact and everyday denial, International J ournal of Inclusive Education, DOI:10.1080/ 13603116. 2011. 580461

To link to this article: http:// dx.doi.org/ 10.1080/ 13603116.2011.580461

\section{(iFirst}

\section{PLEASE SCROLL DOWN FOR ARTICLE}

Full terms and conditions of use: http://www.tandfonline.com/page/terms-andconditions

This article may be used for research, teaching, and private study purposes. Any substantial or systematic reproduction, redistribution, reselling, loan, sub-licensing, systematic supply, or distribution in any form to anyone is expressly forbidden.

The publisher does not give any warranty express or implied or make any representation that the contents will be complete or accurate or up to date. The accuracy of any instructions, formulae, and drug doses should be independently verified with primary sources. The publisher shall not be liable for any loss, actions, claims, proceedings, demand, or costs or damages whatsoever or howsoever caused arising directly or indirectly in connection with or arising out of the use of this material. 


\title{
A critical review of Aboriginal education in Canada: Eurocentric dominance impact and everyday denial
}

Erica Neeganagwedgin*

\author{
218 Queens Quay West, Suite 501-Toronto, Ontario M5J 2Y6, Canada
}

(Received 1 October 2010; final version received 20 March 2011)

\begin{abstract}
This paper provides a historical review of the education system in Canada and its impact on Indigenous women. By doing so, I hope to address the inequities that surround current educational policies and practices. Also in this paper, I critically investigate the salient aspects of the educational experiences of the women in a contemporary context, with their voices and experiences at the forefront, thereby challenging all of us to envision a formal education system that creates space in which women of Aboriginal ancestry are treated fairly and equitably.
\end{abstract}

Keywords: Aboriginal education; anti-colonial pedagogy; ethnicity; race

This paper provides a historical examination of the education system in Canada and its impact on Indigenous people, specifically women. By doing so, I hope to address the inequities that surround current educational policies and practices. Additionally, I critically investigate the salient aspects of the educational experiences of the women in a contemporary context, with their voices and experiences at the forefront, thereby challenging each of us to envision a formal education system that creates space in which women of Aboriginal ancestry are treated fairly and equitably.

Any discussion about the education system and its practices, as they currently exist, would be incomplete without an understanding of the role played by colonialism and residential schooling in the lives of Aboriginal people. And, integral to this understanding of colonial education is to contrast it with what some aspects of Indigenous systems of education looked like prior to European settler domination. In 2006, I conducted a research study where I asked women of First Nations ancestry about their schooling experiences in Canadian contexts. Their accounts also inform this paper. I have used the term First Nations to describe the participants in this paper, who identify themselves as original persons of this land. I am fully aware that this term is also exclusionary as it does not include Métis or Inuit people and that many of these terms are colonially imposed. I chose this term to describe the participants who shared their experiences as none of the women identified herself as Métis or Inuit. I have also used the term Indigenous and Aboriginal interchangeably to include all First Peoples of Turtle Island.

As a person whose ancestry is intertwined with those of the First Peoples of the Caribbean and those Indigenous peoples brought through force to the ancestral

*Email: Erica.neegan@utoronto.ca 
territories of what is now referred to as the Caribbean, I have also been formally educated through a colonial lens not just in the Caribbean context but also in the Canadian context. My interest in this topic stems from my own experiences navigating various levels of formal schooling in Canada. Today being a parent of Mushkegowuk children, my concern is for them and many other children and the impact of the real and present colonial policies in Canadian schools. Currently, many Indigenous people continue to be marginalised as they are inducted into an educational system that rarely includes their histories, heritages and cultural antecedents. I contend that the rupturing of domination, repression and oppression of other groups cannot occur without truly respecting Indigenous peoples and listening to their voices. For these reasons, the educational experiences of Indigenous people, particularly in the context of this study on those of Indigenous women, need to be examined and understood. I utilise Indigenous Knowledges to form a theoretical framework in which to guide my discussion, since Indigenous Knowledges are important when examining histories of colonialism, cultural disruption and Eurocentric imposition in the lives of Indigenous people and, in particular, Indigenous women. Indigenous Knowledges are an integral part of the lives of Indigenous women. These knowledges have sustained them through a school system that many times continues to brand First Peoples as 'Others'. The subjugation and negation of Indigenous Knowledges of First Nations women, as well as of that of other non-European groups, that begun in the colonial period continue today and are reproduced and maintained in many current formal learning institutions. However, Matsinhe (2007) poignantly reminds us that Indigenous peoples have resisted the colonial onslaught and continue to deploy Indigenous Knowledges to construct and organise their social world. Therefore, Indigenous Knowledges offer an important framework from which to make meaning and provide an understanding of the womens' contemporary experiences.

\section{Indigenous Knowledges and the importance of spirituality}

In examining the schooling experiences of women of Aboriginal ancestry, it is, therefore, vital to consider the Indigenous Knowledge framework, which offers a wholistic perspective on learning and thus does not exclude aspects of spirituality from the curriculum. In this paper, it is essential to view the elements of traditional Indigenous education juxtaposed to that of the formal education system in Canada. Doing this requires recognising, as many Indigenous scholars do, the spiritual underpinnings of Indigenous education, as traditionally Aboriginal education did not separate the search for knowledge from learning. Thus, Indigenous Knowledges, by their essential nature, embrace the entirety of being and living. Dei, Hall and Goldin-Rosenberg (2000) describe them as

... the common sense ideas and cultural Knowledges of local people concerning the everyday realities of living. They encompass the cultural tradition, values, belief systems and worldviews that, in an indigenous society, are imparted to the younger generation by Elders. They also refer to the worldviews that come from direct experiences of nature and its relationship to the social world. (p. 1)

Indigenous peoples' ways of learning then are in direct contrast to the Western ways of learning, which separate knowledge from the sacred. This separation permeates the classroom experiences of Aboriginal people and other racialised groups. For example, 
Elabor-Idemudia (1999), who at the age of six was required to attend a Western-style school to acquire a formal education, notes that she was forced to give up traditional Knowledges acquired in both her home and community as they were seen by the school administrators as 'primitive' (p. 106). Wane and Neegan (2007) explain that the experiences of many marginalised peoples are typified by educational practices that negate Indigenous cultures and traditions. Matsinhe (2007) also makes a similar point below:

Indigenous Knowledges and ways of constructing and organizing the social world were suppressed and replaced by Eurocentric worldviews. The modern sciences, natural or otherwise, were and are an integral part of the mechanism of modernization. Their socio-genesis and psychogenesis of their histories of becoming are genocidal. (p. 840)

An Indigenous Knowledge framework is liberatory, as it allows for the revitalisation of Aboriginal education and is a form of resistance that establishes the significance of Indigenous worldviews. Simpson (2004) points out that reclaiming and reproducing Indigenous worldviews and then applying them in a contemporary context represent liberation strategies that Indigenous people can use to free themselves of the bondage of colonialism. Furthermore, Indigenous Knowledges are a means or method towards recovering from the artificial split between mind and body brought about by the theorisation of the Western European Enlightenment thinkers and offer a challenge to the hegemony of Western Knowledges in school curricula and society in general.

According to McCarty et al. (2005), Indigenous peoples worldwide share with many racialised peoples a diasporic history characterised by invasion, colonisation, displacement, enslavement and genocide. Matsinhe (2007) proposes the activation of Indigenous Knowledge systems in research and representations, arguing that, given their attributes, they have the potential of decolonising methodologies. Furthermore, an important aspect of Indigenous Knowledges is that they try to understand systems as a whole, rather than as isolated parts. Forest recognises that, for First Nations people, knowledge is intuitive and spiritual. Similarly, Battiste (2005) asserts that Indigenous scholarship, which is part of Indigenous Knowledge, seeks to transform Eurocentric theory so that it includes and properly values Indigenous Knowledges at all levels of education, curriculum and teaching practices (p. xxi).

Similarly, other scholars such as Matsinhe assert (2007) that Indigenous Knowledges should not be taken as pre- or anti-modern, pre- or anti-science and add that Indigenous Knowledges do not have to be positioned as the opposite of modernity and science. Rather, educators and researchers can embrace Indigenous Knowledges as a gift of humanity in the midst of a heartless modernity (p. 848). But the dominant tendency of European colonisers has been to quash Indigenous Knowledges. However, there are beacons of resistance. Deyhle and McCarty (2007), in examining the work of scholar Beatrice Medicine, make the point that

... racialized educational practices produce resistant, resilient and determined Native students who assert their right to claim and create their lives, languages and future. The failures of the past have exposed the shortcomings of the Eurocentric monologue that has structured modern educational theory and practice. In forcing assimilation and acculturation to Eurocentric knowledge, modern governments and educational systems have displaced Indigenous knowledge. (p. 5) 
Battiste (2005) notes that 'Indigenous knowledge is now seen as an educational remedy that will empower Aboriginal students if applications of their Indigenous knowledge, heritage, and languages are integrated into the Canadian educational system' (p. 15). However, to fully comprehend the magnitude of the effort required to reclaim, revitalise and affirm these knowledges and move voices of Indigenous women to the forefront, it is important to first understand traditional Aboriginal education to apply an appropriate framework towards understanding the historical foundation and impact in the contemporary educational lives of Aboriginal women.

\section{Aboriginal women and traditional education}

An overview of current literature suggests that traditional education of Aboriginal children encompassed all aspects of life. Learning was a continuous process. Adult family members as well as extended family taught what was needed in order for children to become self-sufficient. The extended family of kin and relatives were all teachers, with each member of the family giving something of his/her knowledge to the growing child. This was done so that children would be able to carry on traditions and have the skills necessary for themselves and their community to survive (Aisaican 2001).

Traditionally, even when a First Nations woman was pregnant with a child, she became focused on her responsibility as a life-giver. Everything that she did was reflected and imprinted on the growing child, and great care and attention were taken during every phase of pregnancy (Aisaican 2001). Even before pregnancy, there were ceremonies to welcome a girl into womanhood.

However, education of women was not just restricted to initiations into womanhood and instruction on their role in their community. Beck et al. write that

[There was] an insistence on learning, on education, as an essential foundation for personal awareness. A knowledgeable human being was one who was sensitive to his/her surroundings. This sensitivity opened him/her to the Great Mysteries and to the possibility of mystical learning experiences, which were considered the only way to grasp certain intangible laws of the universe. (Beck, Walters, and Francisco 1977, p. 48)

Traditional ways of learning were wholistic and permeated all aspects of the child. The impact of the historical legacy of residential schooling in the lives of First Nations women directly collides with the Indigenous ways of learning and seeing the world, and this clash of worldviews continues to this day.

\section{Residential school experiences in Canada}

The fact that First Nations people had highly developed education systems in place before European contact must not be ignored or undermined. Traditional First Nations education focuses on a four-dimensional approach balanced to meet the emotional, mental, physical and spiritual needs of the learner (Kainai Board of Education and others 2006). Cree Elder Peter Waskahat reminds us of the rich culture of his people:

We had our own teachings, our own education system teaching children that way of life. They were taught how to view, to respect the land, and everything in Creation. Through that, the young people were educated about what were the creator's laws, what were these 
natural laws, what were these First Nations laws. And talk revolved around a way of life, based on their values. For example: to share, to care, to be respectful of people. How to help oneself. How to help others. How to work together. (p. 173)

One of the goals of the Canadian government was to rid Indigenous peoples of their cultural identities, especially their languages. While ideologies about the inferiority of Aboriginal people became more and more rampant, the opening of residential schools in Canada by the government and churches reinforced that perceived inferiority of the 'Other' in the treatment of many of the children who attended these schools. From the perspective of the Canadian government, the goal of the schools was to assimilate First Nations peoples into what had now become the dominant European society. This imposed form of education was to teach children and their families and communities that their ways of life were lesser than those of the settler European society (Miller 1996, p. 208 as cited in Neegan 2005, p. 6). In fact, Miller notes that when European missionaries began to live among Indigenous people, it was concluded that the sooner they could separate children from their parents the sooner they could prepare them to live a 'civilised' life.

First Nations leaders did not ask for an educational system to change their cultures. Nor did they ask for teachers and administrators who would try to convert First Nations children to Christianity. Rather, they believed in the treaty promises to preserve their own ways of life, values and governing authority (Kainai Board of Education and others 2006). Importantly, for First Nations leaders and their communities, there was the expectation that this education would add to their children's cultural framework. It was not to rid their own ways of educating their children (Kainai Board of Education and others 2006). James Youngblood Henderson affirms that 'First Nations people never delegated to the Crown any role in educating their people. Aboriginal choice continues as a constitutional obligation, which has never been extinguished' (as cited in Beynon 2008, p. 36).

While many residential school survivors have shared their experiences over the past 20 years, the following section of this paper provides accounts of the experiences of women who attended those schools. Being able to acquire an education, whether traditional or Western, is part of Aboriginal governance. And, women in traditional Indigenous communities participated equally in governance. Residential schools, by their very nature, would debase that equality.

\section{Female perspectives of the residential school experience}

Many residential school survivors continue to share their stories and narratives of their experiences within these schools. For example, one survivor recalls 'we had Dick and Jane, Spot, stories .... I thought, who are these people and who lives like that?' (Jack 2000, 157). The colonial, Eurocentric, forced education on Indigenous children, their families and communities undermined their people's worldviews. For instance, there is a significant difference in the Indigenous view of menstruation, or moon time as it is referred to by many First Nations people. Menstruation was central to the understanding of creative female energy, and Anderson (2000) notes that it is still evident in many First Nations communities where women who are menstruating do not participate in ceremonies due to the powerful energy they are said to have at those times (p. 74). When interpreted with a Western lens, menstruation is seen as impure and evil, it is the opposite view in many Indigenous communities. Anderson (2000) reminds us 
that Judeo-Christian culture saw menstruation not as a manifestation of female power but as a manifestation of female sin, contamination and inferiority (p. 75). In her work, Anderson discusses the difficulty that First Nations girls going through puberty experienced in residential schools. 'There was no recognition of menstruation as a rite of passage, instead theirs was a rite of passage based in shame and sin' (p. 75).

Even more traumatic were instances of sexual abuse at the schools. But one residential school survivor recounts her experience of sexual abuse at the school as a moment of resistance. 'I remember wanting to tell somebody, but I didn't know who I could tell that would help me. Then all of us girls got together, ten of us, and we all said we'd never leave each other' (p. 63). For these women, the residential school emerged as a site of support for each other and resilience.

While most narratives indicate that the majority of residential school survivors had negative experiences at the schools, there are survivors who claim to have had positive experiences. As argued in Beynon (2008), historian Jean Barman reminds us of the contradiction between official oppression and individual goodwill (p. 63). Barman asserts that while teachers and administrators of goodwill were able to ameliorate the worst aspects of the system for some students, all of the individual goodwill in the world could not have rescued a system that was fundamentally flawed. Another residential school survivor recalls feeling elated to learn that a First Nations administrator was at the school:

... it was like a dream come true because before the food the students were provided with often was tasteless and made them sick. This administrator came in and, as pointed out by the survivor, we were having waffles and boiled eggs he was a godsend .... I have so much respect for him .... He put his job on the line in just one month to do what he did. They must have saved tons of money on food before he ate with us and stood in line with us. (Jack 2000, p. 52).

The survivor also notes that the administrator was once a student at the school and thus could empathise with the current students. According to Barman, while these individual acts of kindness are valued, they do not take away the fact that the schools were part of an intentional and systemic plan by the Canadian government to annihilate First Nations peoples' cultures, languages and worldviews (2008).

On 11 June 2008, Canadian Prime Minister Stephen Harper issued a public apology to the living survivors of residential schools for the abusive treatment that they experienced at these government and church-sanctioned schools. Unfortunately, many residential school survivors have passed on and will never know of this apology. However, the apology is worth little if not followed by concrete action to redress past and present wrongs, a sentiment echoed by many First Nations people, including Beverly Jacobs, former president of the Native Women's Association of Canada (NWAC). Jacobs speaks about the dishonour that First Nations grandmothers and mothers experienced in the hands of the residential school system (Fiddler 2008, p. 8). Similarly, Fiddler (2008) points out that the closing of residential schools does not mean that the pain experienced by First Nations communities has stopped. In fact, the trauma suffered by many First Nations people in these schools has been passed down through generations of families where communities have and continue to be impacted and disrupted by the legacy of these colonial educational institutions (Fiddler 2008). According to Monture-Angus (1996), Aboriginal people understand Western education for what it has been - a tool of oppression (p. 95).

Bowker (1993) states that 'Despite the fact that Aboriginal peoples are diverse from one nation to another, many general stereotypical characteristics are commonly 
attributed to Aboriginal peoples in contemporary society' (p. 86). Many First Nations women, in particular, have borne the brunt of such stereotyping in Western schools. Bowker writes that early European education efforts focused on teaching the women domestic skills. For example, sewing, cooking and homemaking were the focus of the curriculum for First Nations women. It was believed that this type of education would turn them into the stereotypical ideal of European women. And any other attention given to the education of First Nations women during this early period was usually for the purpose of promoting 'civilisation' among the men. As a result, First Nations women were construed as inferior vis-a-vis men. An overwhelming Eurocentric and patriarchal belief in their cultural superiority lay at the core of such constructions. Chisholm (1994) emphasises that the systematic oppression of First Nations peoples was likely justified by a belief in evolutionary superiority and that First Nations peoples existed in a savage, primitive state that European society had long surpassed. While the closing of residential schools has been a positive step, unfortunately, it has not resulted in ending Eurocentric schooling of First Nations students, as Eurocentric ideologies continue to be dominant in many school systems and curricula within Canada.

In the following section, I provide accounts of some aspects of the contemporary schooling experiences of First Nations women between the ages of 18 and 40 years in Canadian formal institutions. The interviews were conducted in 2006, and the participants attended various educational institutions across Canada.

\section{Contemporary perspectives on First Nations peoples' educational experiences}

Although residential schools are closed, many of the assimilationist intents continue in the education system today. Aboriginal education, as currently administered through the Canadian education system, is often not regarded as important. Such a circumstance helps to explain why First Nations females in Canada are 16\% less likely to complete high school and $20 \%$ less likely to complete university than non-First Nations women (Give Girls a Chance 2005). Still, many First Nations women believe that formal education is important to a healthy future for both themselves and their communities. Some point to the legacy of residential schooling and coping with a Eurocentric curriculum as factors for the higher dropout rates among Aboriginal people.

Thus, it must be reinforced that long before the European missionaries and colonisers, Indigenous people had thriving cultures that in many ways eclipsed those of the colonisers. First Nations women have all too often encountered negativity in their schooling experiences. The following two personal stories illustrate this. A friend told me that her five-year-old daughter was challenged by her teacher when she proudly proclaimed that 'my ancestors were the original people of Canada'. Although her teacher's response was tantamount to invalidating the truth of the remark, the young girl resisted and replied 'Well my mommy told me so' (Gloria Thomas, personal communication, March 12, 2005).

Another friend related the story of how her eight-year-old daughter, the only First Nations student in her class, was humiliated by the teacher when she spoke about how her ancestors helped the European newcomers to survive the harsh climate. The teacher told her that it was the other way around (Gloria Thomas, personal communication, January 22, 2005). So, some teachers today, much like some of the missionaries and nuns decades ago, frequently discount Aboriginal people and deliberately strive to maintain European dominance.

Devaluation of Aboriginal peoples and their worldviews is experienced by some First Nations children from a very early age. As Anderson (2000) states, 'To be 
Native was uncivilized; to be female inferior, but to be a combination of the two was particularly base' (p. 139).

Many of the challenges that First Nations women faced in contemporary society remain. In her study of some of these barriers created by Canadian government policies, Kenny (2004) argues that education was found to be the way to gain increased leadership for First Nations women. However, this thrust for 'increased leadership' cannot be addressed without first acknowledging the traditional leadership roles that Indigenous women of Turtle Island once held. The Cherokee, like many other First Nations peoples, were matrilineal, and as Hightower-Langston (2003) states: Women had a great deal more status and power than European women of the eighteenth century. Americans referred to them as a 'petticoat government' because of the prominent role women had in civil and war councils (p. 98). It is important to note that such involvement by First Nations women in governance is not a new direction but is reclamation of their traditional roles. The Euro-dominated school system has seriously undermined Aboriginal students' identity as well as the role of First Nations women in their own communities.

Hampton (1995) asserts that schools are detrimental to First Nations cultures:

The contemporary North American school is a political, social and cultural institution that embodies and transmits the values, knowledge and behaviours of white culture. The structure ... is hostile to Native cultures in ways that seem unavoidable to white educators, [with] age-segregated classrooms, Natives as janitors and teacher aids, role authority rather than kin and personal authority, learning by telling and questioning instead of observation and example, clock time instead of observation. All these and more are structural features that undermine the Native child's culture. (p. 37)

Common themes that existed more than 100 years ago still persist in the current school system in Canada. For instance, colonialism, paternalism and historical omissions of First Nations students' cultures and communities are some of the major driving forces in some Canadian schooling institutions from kindergarten to post-secondary schooling, and they come across in the experiences of the women who shared their experiences with me.

With some of the women, the ubiquitous hand of the Canadian government has an intrusive and often paternalistic impact on their sense of self. For instance, Chepi's experiences with the federal Department of Indian and Northern Affairs highlight this dynamic that many First Nations people face in their pursuit of education, she notes

Everything had to be done through Indian Affairs. They choose the school and the place where you were going to stay, and they gave you an allowance. They could not wait to insult you. I stopped going to get my allowance. They called the boarding home where I was staying and asked me why I wasn't picking up my allowance. I decided to keep my dignity. I wasn't the only one they treated this way as it was all the Native kids that they were doing that to as well. So when I went back to university, I paid for my own courses.

The extent to which First Nations students (those who did not share their experience) feel, or felt, the same as Chepi and reacted similarly cannot be known. However, Chepi's desire for educational independence from the foreign and colonial state is clear and reflects some of the barriers faced by many Indigenous peoples historically and even in contemporary times. It has to be kept in mind that her ancestors had their own ways of teaching and learning prior to this newcomer government and that 
these worked effectively and efficiently. Likewise, it is necessary to note that Indigenous people have always had the education of their children in their hearts. Thus, treaties signed with the newcomers covered education as a priority for many Nations in their negotiations with the European settler government.

Monture-Angus (1996) emphasises that reclaiming their place in formal education will be a difficult task for Aboriginal peoples. It will require considerable patience, as schools in Canada have historically been part of the government's plan to assimilate Aboriginal people. She asserts that Aboriginal students

... must question if education institutions that were founded on Aboriginal inferiority are really part of the answer or has education been part of the problem. Aboriginal People need to depend on the creativity of all First Nations people and must learn to rely on themselves and not on institutions of colonial governments .... We must always have in our sights the process and nature of our oppression and colonization. Education is important if and when we are able to educate our young in a decolonized way. Colonialism and its consequences are the obstacles. (p. 80)

Within the context of Chepi's experiences and Monture-Angus's statement, one can more readily understand the experiences of another participant, Alsoomse:

School's not hard; it's just extremely boring. They fill your head with all this stupid knowledge. I just don't like it. I really don't like that everything is all White. I remember negative things. I guess you could say that they are more prominent in my mind, like Grade 4, reading about the red savages.

It is not surprising that Alsoomse 'just didn't like' school. The insensitivity and White supremacy in the content of a textbook that describes Aboriginal peoples as 'red savages' are blatant. Wilson (2006), in challenging a school text, notes that some people from the dominant culture cannot see that there is a problem, because it is a system that helps them maintain their superiority (p. 70). There is, after all, an interest in maintaining the status quo. And Wane (2005) argues that when dominant history denies us access to our past, belittles that past or ignores it, we suffer amputation from the very roots meant to give us life (p. 131). Similarly, in her discussion on White privilege, Mathieson (2002) asserts that 'the curriculum is White and Eurocentric, grounded within a White patriarchal, heterosexist, middle-class system of values tied in complex ways to the interests and knowings of the West'. Sokanon, an Anishnabe participant of mixed ancestry, shared her early experiences of a Eurocentric curriculum:

When I was young I went to a Catholic school. It was like a Native Studies curriculum and I found some materials that we used. There was a papoose and there was a little baby, and it said 'God's Love is warm and snugly, like an Indian papoose'. You had to write it out, to practice your printing, and I drew myself as having blonde hair and peachy skin tone. I have peachy skin tone but not blonde hair. I remember singing horrible songs about Native People ... all these really horrible songs.

And it does not end there, as Sokanon recounts yet another of her experiences of bias in the school curriculum, she asserts:

I remember that in Grade 5 we did a project about Native beliefs, and my mom had some cards that were really good; they talked about Native beliefs. So I learned a thing about Native beliefs and pipes and the four directions. But [in class] we took notes from 
history books that were really ridiculous and omitted a lot. We never really had any curriculum that situated Canada as a settler state. We never learned about history of oppression within Canada.

Sokanon's concern about Canada not being recognised as a 'settler state' or the denial of Canada as a 'settler' state is important, as it reinforces how Indigenous people and their cultures have been undermined and supplanted in the curriculum with lies or by distortions through both omission and commission. It should also be noted that her understanding of her First Nations culture was largely derived from the information provided by her mother and not by the school.

Hooks (1992) argues that within White supremacist capitalist patriarchy, forgetfulness is encouraged. I believe that it is not only forgetfulness that is encouraged, but also denial. Alsoomse makes the following observation: 'I remember that we supposedly lived in Tepees. We hunted buffalo and ate them and used every piece of them and didn't waste them. They teach a lot of courses that I think have no meaning. They can teach better things in school, right?'

The curriculum, then, as observed by Alsoomse, had little or no relevance to her, as she says the courses 'have no meaning'. The idea that First Nations peoples lived in tepees and hunted buffalo may be true for some, but it does not capture the whole reality of all First Nations people. There are vast complexities of First Nations experiences. And it may be assumed that these missing aspects are implicit in Alsoomse's comment that 'they can teach better things in school'.

In proposing steps towards a theory of First Nations education, Hampton writes that spiritual concerns are an important part of such education. However, any research on First Nations education cannot be complete without an understanding of the oppression underlying Aboriginal students' experience and the resistance they offer (Churchill 1981; Deloria 2006). Lavell-Harvard (2005) describes the particular struggle of First Nations people in the contemporary education system:

\begin{abstract}
As an Aboriginal woman who has struggled for many years within the current education system as both a student and a teacher, I have become increasingly aware of the difficulty that an overwhelming majority of Aboriginal people experience within the confines of mainstream educational institutions. We have long believed that the problems faced by our students, specifically and arguably by all marginalized students generally, are not the result of inherent inferiority or cultural deprivation as previous research has often claimed, but are symptoms of a system that has historically filed to meet the specific needs of our communities. (1)
\end{abstract}

And Clark (2005) writes 'The big shortcoming of the school system for Aboriginal students is that separate and isolated disciplines are most often not clearly related to any sort of "real-life" applications. Students must acquire the content of the lessons through abstract lectures, memorization, and drill. Too often the content learned from this system is lost to the student shortly after the final test' (p. 5). There is an assumption in Western teachings that the beginning of formal education can be traced to ancient Greece or Rome. This common ideology negates many other cultures that had their own established formal ways of teaching and learning. Yet, many people who 'educate' continue to project this Eurocentric bias. As Battiste (2005) puts it, 'Several strategies have been used to reinforce the myth that regions outside Europe contribute nothing to the development of knowledge, humanities, arts, science, and technology (p. 1)'. 
As mentioned, contemporary Western schools continue to foster and disseminate Eurocentric knowledges as the ideal while ignoring both historical antecedents and traditional Indigenous Knowledges and history. As Dei et al. (1997) point out:

Problems of representation, whether with respect to the absence of role models or in the abstract production of knowledge, and issues of identity are closely tied .... As students, parents, and educators reflect on questions of identity and issues of Eurocentrism within schools, they explore alternative visions for the delivery of education. (p. 168)

Clark (2005) asserts the need for culturally congruent school reform and points out that standardised tests, as an influential force in deciding school policy and practice, have been used to identify academic deficiencies in Aboriginal students, thereby giving educators the empirical 'evidence' to stream them into dead-end basic-level classes (p. 4). Clark calls for the adoption of a fundamentally different approach to teaching Aboriginal students. I believe that this includes a school system that is both accountable and inclusive to all students.

\section{They do not expect much from us}

As I found in my discussions with the women, biased curriculum is not the only challenge that many Aboriginal people face in school. There is also the matter of low expectations from some teachers. In fact, when many of the women were questioned regarding their most memorable experiences with teachers, whether negative or positive, a similar theme emerged, as the women shared their accounts of how they felt that teachers' assumptions and expectations of them influenced their schooling and their lives. Overall, the recollections of most of the women point to feelings of disillusionment engendered by their teachers. Chepi stated that 'I' $\mathrm{d}$ been raised on the reserve, and leaving my family was a cultural shock more than anything else. Imagine, the teacher put me in lower level classes although I had scored 80 s and 90 s in high school'.

Nelson claims that a high number of Aboriginal students are placed in special education classes or in programmes for the emotionally and behaviourally disturbed. By doing this, a negative message is sent to these students' peers. Consequently, two reactions often emerge: (1) First Nations students may not want to be identified as First Nations people, because they see so many students from their cultures in these types of programmes, and (2) First Nations students become afraid of being teased or marginalised by their non-First Nations peers. Kimi, another participant who attended school outside of her community, expressed her experience as follows:

I liked going to school and learning new things. I liked it when I felt I wasn't excluded. There were times when teachers and peers would assume that because I am different, I am not as intelligent. I don't know if it was a conscious decision by everyone else not to include me. But I definitely felt excluded.

Kimi continued:

Sometimes I'd have a teacher skip over me. I wrote a paper and gave it to the teacher. I got a crappy grade. I didn't deserve it, and I wondered if it was because he's making assumptions about me. For example, one day in class the teacher asked questions about why when Europeans came did a lot of Native people die. Everybody else said because of war, and I said because of disease. I put lots of additional stuff in there. I remember he ignored it all, 
and I was pissed. I've talked to many other people that have gone to school off the reserve and they have had problems.

Kimi's account of being ignored in school illustrates a systemic bias among many teachers towards Aboriginal people. Leiding (2006) notes that teachers must engage in self-awareness activities and (i) examine their attitudes regarding students not of the dominant culture, (ii) be exposed to correct information and (iii) be able to demonstrate effective interactions among colleagues, students and families, further noting that too many students fail as a result of the school ignoring or degrading their communities and backgrounds. Such denigration is often directed not only against communities or groups, but against the student also.

Hurit, a participant, in her account proffered another example of what she calls teacher racism. 'I was in the back of the [French] class, just doing my work, and he pointed to me and asked, "Do you understand this?" There were other English-speaking students there and I was the best French-speaking student, yet he singled me out to ask if I understood'. And similarly Otta Dabun, while she has had negative assumptions made by teachers, also shared her positive encounter with one teacher:

There was a teacher in Grade 6 that I remember; he just paid attention to me when my other teachers didn't. It made me want to do better, you know what I mean? He had me tested to go into a gifted class because he thought I wasn't doing very well because I was bored with the work.

Research shows that many First Nations students are often 'put back' into special education classes or a grade lower (Brathwaite and James 1996; Dei 2000, 2002; Solomon 1992). In this study, many of the women commented that many teachers often assume that students are not academically bright and try to place them in grades lower than their potential. The influence of the teacher in assessing a student's potential is such that many students internalise the views of their teachers. I know from my own schooling experiences that this internalisation can have serious implications for students. Additionally, previous research findings suggest that instead of valuing all students and treating them all as having good prospects, some teachers may suspect that disadvantaged students and students who are minority group members are intellectually inferior. In turn, these students may feel rejected by teachers, their peers and the curriculum (Brym, Lie and Rytina 2007). This was the case with Chepi. However, with Otta Dabun, her teacher assumed that she was a gifted student and did not share the negative views of her held by other teachers. The women's experiences indicate that despite the times when participants found a teacher who ruptured the educational status quo as regards negative behaviour towards Aboriginal students, a persistent and pervasive negative climate permeated the relationships between teachers and these students. One participant, Nadie, summed up the characteristics of what she considers a good teacher: 'What I like about the teachers, the good teachers that I've experienced, is that they were quite helpful. They were quite compassionate and thoughtful. They went the extra mile, beyond the call of duty, to help me get ahead'.

In fact, many First Nations students have also had to bear the brunt of teacher pessimism. In a study on the experiences of First Nations students in a Winnipeg urban high school, the female respondents said that they got along well with their teachers when they were in school and that their teachers cared about how well they did and were supportive of their efforts. Yet, only a small proportion of female respondents believed that 
teachers understood them or understood First Nations students generally. Some of the comments made by those who are not now in school suggest that there is a continuous divide between Aboriginal students and non-Aboriginal teachers (Silver et al. 2002).

Oneida scholar Antone (1997) described a personal secondary school experience when after her math teacher agreed to help students who needed assistance, 'she promptly informed me she was too busy and had no time to help me with my work, and if I would only read the text, the information would be right there'. She asserts that 'it is still a difficult struggle even today to ask anyone for help in my studies due to this negative experience' (p. 27). The classification of Indigenous students as low achievers with poor motivation and limited chances of success is a continuing legacy of society's historical denial of Indigenous peoples. The Royal Commission on Aboriginal People (RCAP), which reported on the pervasiveness of colonialism in the Canadian school system and its impact on First Nations peoples, stated

There is an overwhelming lack of support for Aboriginal identities, no Aboriginal high school teachers; only limited curriculum dealing with contemporary Aboriginal languages, cultures, history and political issues; an emphasis on intellectual cognitive achievement at the expense of spiritual, social and physical development; and the marginalization of youth in decision-making about their education. The result is that the schooling system typically erodes identity and self-worth. (RCAP, 1996)

The Toronto District School Board's (TDSB's) Aboriginal Studies secondary curriculum confirms RCAP's findings. Of the board's eight courses dealing with First Nations, Inuit and Métis content from Grade 9 through to Grade 12 in 2005, only three are currently being offered (TDSB, 2005). The TDSB (2010) website indicates that little has changed over the past five years. For example, there are still eight courses in the grade 9-12 curriculum that reflects Aboriginal content and only three courses are currently being offered. Undoubtedly, still much more needs to be done in terms of incorporating Aboriginal worldviews into the curriculum. As noted by Steckley and Cummins (2008), Europeans have been in the Ontario region for 400 years; therefore, they are newcomers to this territory. Steckley and Cummins further note that only $4 \%$ of history is European history and $96 \%$ is Aboriginal history. Why is then the curriculum so Eurocentric? Should not the history that we learn in school be primarily that of the First Peoples? As mentioned earlier, Indigenous peoples and communities have been here since time immemorial with their own educational systems. The TDSB's Anishnawbek education consultant, Eddy Robinson, reminds us all that 'The history of Canada begins with Aboriginal peoples, noting "The histories of First Nation, Inuit and Métis peoples are an integral part of Canada's history; we must never forget that'. I agree wholeheartedly that we must not forget'. Multicultural window dressing or surface accommodation is no longer an acceptable or viable option.

Many Aboriginal students have identified that most aspects of the curriculum are not related to their experiences and did not resonate with what they already know. Particularly, they view many of the textbooks used as outdated and having little relevance to their learning. In the study by Silver et al. (2002), Aboriginal high-school students answered in the affirmative when asked whether they thought that more Aboriginal content in the curriculum matters to them. Many students noted the lack of knowledge of Aboriginal cultures and languages among Aboriginal youth and their desire to know more about themselves and their culture and history.

The Native Women's Association of Canada asserts that educational programmes from kindergarten to post-secondary levels must be enhanced with accurate, historical 
Aboriginal content and appropriate cultural teachings. And Aboriginal women must be integral to the design, development and delivery of curriculum and research design throughout all institutions (NWAC, 2004). The need for this is urgent, as there are few courses with Indigenous content, and they are not mandatory to the curriculum as demonstrated by the TDSB curriculum.

\section{Conclusion}

Several factors emerge as salient to an understanding of the causal factors that adversely affect identity, learning and overall academic performances of First Nations students in Canadian educational environments. Although teachers do not shoulder the sole responsibility, they are shown to be actors of importance, regarding students' successes and failures. The classification of Indigenous students as low achievers with poor motivation and limited chances of success is a continuing legacy of society's historical denial of the selfhood of Aboriginal students.

I believe that it is time to critically examine the complicity of the colonial school system with its White supremacy ideologies as the potential source of the problem of low academic achievement as it pertains to Aboriginal students. Far too many studies have held the parents, students and their communities accountable without acknowledging and then addressing institutionalised discrimination against Indigenous students. Education has been a major vehicle through which the implementation and maintenance of colonialism have been pursued. The education system is undoubtedly flawed in this regard and requires serious reconstruction of the curriculum so that learning is not approached solely from a Eurocentric standpoint but rather from the standpoint of inclusion of the histories, worldviews and cultures of Aboriginal peoples and their cultures who have given much to all aspects of Canadian society and who request nothing more than equitable practices and policies from an educational system that is noted for its defects. Case (2002) states

There is an increasing demand for the contributions of marginalized peoples to be mentioned in school textbooks and to be discussed in schools. It is also necessary for the history of racism in Canada to be taught so that a basic misconception of Canadian history be dispelled (p. 101).

Wane (2005), in her paper titled 'Creating Meaningful Global and Local Dialogues in Our Classrooms', states

As educators interested in social change, it is imperative that we explore more effective ways to provide our students with strategies to take on the challenges associated with working in areas of greatest need. To teach ethically requires that we develop a more inclusive curriculum. We can no longer avoid these issues if we are committed to developing a more equitable system of education for future generations. (p. 13)

Hampton's earlier analysis of the devastating impact of the school system on students' cultural identities and self-worth reinforces what was historically known about a foreign-imposed, exclusive flawed system that continues to impose Eurocentric and Whiteness as ideologies on even those who are considered White. Far too many Aboriginal students and those from various marginalised communities have had their spirits injured in and by an education system that operates on what I consider as psychological exclusivity. Jones (2003) reminds us that 'the spirit is the part deep within you that makes you who you are. Factors such as the loss of culture and the abuse and 
trauma experienced in elementary and secondary school systems lead to a broken spirit' (p. 50). Nevertheless, Aboriginal people continue to reclaim education of their children from their own perspectives.

The question that we all need to ask ourselves is where do we go from here? This is a matter of urgency for those interested in making education inclusive, equitable and engaging for all students.

\section{Notes on contributor}

Erica Neeganagwedgin currently teaches at the University of Toronto. Her research interests include Indigenous Knowledges, cross-cultural relations, spirituality, anti-colonial thought and decolonising pedagogy.

\section{References}

Aisaican, R. 2001. Aboriginal post-secondary education, a priority for aboriginal women of Canada. Unpublished bachelor's thesis. Malaspina University-College, British Columbia, Canada.

Anderson, K. 2000. A Recognition of being: Reconstructing native womanhood. Toronto: Second Story Press.

Antone, E. 1997. In search of voice: A collaborative investigation on learning experiences of the ONYOTAA: KA. Unpublished doctoral diss., Ontario Institute for Studies in Education of the University of Toronto, Toronto, Ontario, Canada.

Battiste, M. 2005. Indigenous Knowledge: Foundation for First Nations. World Indigenous Nations Consortium Journal. http://www.win-hec.org (accessed August 20, 2008).

Beck, P.V., A.L. Walters, and N. Francisco. 1977. The sacred: Ways of knowledge, sources of life, 48-330. Arizona: Navajo Community College.

Beynon, J.D. 2008. First Nations Teachers: Identity and community, struggle and change. Calgary, Alberta: Detselig Enterprises Ltd.

Bowker, A. 1993. Sisters in the blood: The education of women in Native America. Newton, Massachusetts: Women's Educational Equity Act Publishing Centre.

Brathwaite, K., and C. James. The education of African Canadians: Issues, contexts, and expectations.. 1996. In Educating African Canadians: Our schools/our selves, ed. K. Brathwaite and C. James, 13-31. Toronto: James Lorimer and Company Ltd.

Brym, Robert, Lie, John, and Rytina, Steven. 2007. Sociology: Your Compass for a New World Second Canadian Edition. Toronto: Thompson-Nelson.

Case, F.I. (New revised and edition, 2002). Racism \& national consciousness, 100-1. Toronto: Plowshare.

Chisholm, S. 1994. Assimilation and oppression: The northern experience; education and the Aboriginal adolescent. Education Canada, Toronto 34, no. 4: 28.

Churchill, W. 1982. White studies: The intellectual imperialism of contemporary U.S. education. Equity \& Excellence in Education 19, no. 1-2: 51-7.

Clark, R. 2005. Congruent school reform: A call to action, for title IX Indian education programs and parent committees. http://www.sfu.ca/mpp/aboriginal/colloquium/pdf/ Advocating_Reform.pdf (accessed July 16, 2006).

Dei, G.S. 2000. Introduction. In Indigenous Knowledge in Global Contexts. Multiple Readings of Our World, ed. G. Dei, B. Hall and D. Goldin Rosenberg, 1-18. Ontario Institute for Studies in Education, Toronto: University of Toronto Press.

Dei, G. S. 2002. The resistance to amputation: Spiritual knowing, transformative learning and antiracism. OISE: University of Toronto.

Dei, G.S., B. Hall, and D. Goldin-Rosenberg. 2000. Introduction. In Indigenous Knowledges in global context-multiple readings of our world, ed. G.S. Dei, B.D. Hall and D. GoldinRosenberg. Toronto: University of Toronto Press.

Dei, G., J. Mazzuca, J. McIssac, and J. Zine. 1997. Reconstructing 'drop out': A critical ethnography of the dynamics of Black students' disengagement from school, 64-194. Toronto: University of Toronto Press. 
Deloria, V. 2006. Conquest masquerading as law. In Unlearning the language of conquest: Scholars expose anti-Indianism in America, ed. Four Arrows, aka D. T., Jacobs, 94-107. Austin: University of Texas Press.

Deyhle, D., and McCarty. 2007. T.L. Beatrice Medicine and the anthropology of education: Legacy and vision for critical race/critical language research and praxis. Anthropology and Education Quarterly 38, no. 3: 209-20.

Elabor-Idemudia, P. 1999. Gender and the new African diaspora: African immigrant women in the Canadian labour force. In African origins and the New World identities, ed. I. Okpewho, C. Davis and A. Mazrui, 233-54. Bloomington: Indiana University Press.

Fiddler, C. 2008. Gov't of Canada apologise for 100 years of atrocities. Windspeaker 26, no. 4: $1-27$.

Give Girls a Chance Inc. http://www.givegirlsachance.org/ (accessed August 6, 2005).

Hampton, E. 1995. Towards a redefinition of Indian education. In First Nations education in Canada: The circle unfolds, ed. M. Battiste and J. Barman, 5-46. Vancouver: University of British Columbia Press.

Hightower-Langston, D. 2003. The Native American world. Hoboken, NJ: John Wiley \& Sons, Inc.

Hooks, B. 1992. Black looks. Boston: South End Press.

Jack, A. 2000. Behind closed doors: Stories from the Kamloops Indian residential school. Kamloops, B.C: Secwepemc Cultural Education Society.

Jones, C. 2003. Self-management and self-direction in the success of Native literacy learners. Canadian Journal of Native Education 27, no. 1: 45-58.

Kainai Board of Education, Métis Nation of Alberta, Northland School Division and Tribal Chiefs Institute of Treaty Six. 2006. Peoples and cultural change: Aboriginal studies 20. Edmonton: Duval House Publishing.

Kenny, Carolyn. 2004. A holistic framework for Aboriginal Policy Research. Ottawa, ON: Status of Women Canada.

Lavell-Harvard, D. Memee. 2005. Until our hearts are on the ground: Aboriginal mothering, oppression, resistance and rebirth. Bradford, ON: Demeter Press.

Leiding, D. 2006. Racial bias in the classroom. Toronto: Rowman and Littlefield Education.

McCarty, T.L., T. Borgoiakova, P. Gilmore, K.T. Lomawaima, and M.E. Romero, ed. 2005. Indigenous epistemologies and education: Self-determination, anthropology, and human rights. Anthropology \& Education Quarterly 36, no. 1: 1-7.

Monture-Angus, P. 1996. Thunder in my soul: A Mohawk woman speaks. Nova Scotia: Fernwood Publishing.

Mathieson, G. 2002. Reconceptualizing our classroom practice: Notes from an anti-racist educator. In Back to the drawing board, ed. N. Wane, K. Delivosky and E. Lawson, 158-96. Toronto: Sumach Press.

Matsinhe, M.D. 2007. Quest for methodologies alternatives. Current Sociology 55, no. 6: 83656.

Miller, J.R. 1996. Shingwauk's vision: A history of native residential schools. Toronto: University of Toronto Press.

Native Women's Association of Canada. 2004. Life long learning from the womb to the tomb. http://www.nwac-hq.org (accessed September 8, 2005).

Royal Commission on Aboriginal Peoples (RCAP). 1996. Report of the royal commission on Aboriginal peoples. Vol. 3, Gathering strength. Ottawa: Canada Communication Group.

Simpson, L. 2004. Anticolonial strategies for the recovery and maintenance of indigenous knowledge. American Indian Quarterly 28, no. 3: 373-77.

Silver, J., K. Mallet, J. Greene, and F. Simard. 2002. Aboriginal education in Winnipeg inner city high schools. Winnipeg inner-city research alliance: Canadian centre for policy alternatives-Manitoba. http://ius.uwinnipeg.ca/pdf/aboriginal-education.pdf (accessed August 3, 2007).

Solomon, Patrick. 1992. Black resistance in high school: Forging a separatist culture. Albany: State University of New York Press.

Steckley, J.L., and B. Cummins. 2008. Full Circle: Canada's First Nations. Toronto: Pearson Education Canada.

Toronto District School Board Website. http://www.tdsb.on.ca (accessed June 26, 2005).

Toronto District School Board Website. http://www.tdsb.on.ca (accessed June 29, 2010). 
Wane, N. May 2005. Creating meaningful global and local dialogues in our classrooms. Paper presented at the International Education Conference, London, Ontario, Canada: University of Western Ontario.

Wane, N., and E. Neegan. 2007. African women's indigenous spirituality: Bringing it all home. In Theorizing empowerment Canadian perspectives on Black feminist thought, ed. N. Massaquoi and N. Wane, 27-46. Toronto: Inanna Publications and Education Inc.

Wilson, A.C. 2006. Burning down the house: Laura Ingalls Wilder and American colonialism. In Unlearning the language of conquest: Scholars expose anti-Indianism in America, ed. Four Arrows, aka D. T. Jacobs, 66-80. Austin: University of Texas Press. 